\title{
The importance of systematical analysis and evaluation methods for energy business ecosystems
}

\author{
Zheng Ma*
}

\author{
*Correspondence: \\ zma@mmmi.sdu.dk \\ SDU Center for Energy \\ Informatics, Mærsk \\ Mc-Kinney Møller Institute, \\ University of Southern \\ Denmark, Campusvej 55, \\ 5230 Odense M, Denmark
}

In recent years, business ecosystems have gained popularity in many sectors due to the increasing awareness of the value of being part of an ecosystem or creating their own ecosystems. This trend is observed for leading Tech companies, such as Apple, Google, Microsoft, and Alibaba, who have become platform ecosystem leaders.

However, business ecosystems in energy are relatively less researched than other sectors, and many studies in the energy sector are still at the device or the system levels. A business ecosystem modelling framework is proposed by (Ma 2019) and applied in the energy sector with examples in (Ma et al. 2017, 2019).

Although a business ecosystem architecture development methodology is proposed being part of the business ecosystem modelling framework (Ma et al. 2021), how to systematically analyze energy ecosystems and efficiently identify opportunities and solutions that can benefit the ecosystem and its stakeholders remain unclear.

\section{The missing literature in business ecosystems research}

The studies on the impact factors in business and strategies can be tracked from ETPS (Economic, technical, political, and social) (Aguilar 1967), STEP (Social, technical, economic, political) (Brown and Weiner 1984), and STEPE (Social, technical, economic, political, and ecological) (Davenport and Prusak 1997). Later on, many related acronyms are proposed whereas PEST becomes the most popular one. However, the main focus of these impact factors is individual and organizational strategies, and the business ecosystem perspective is not considered.

In the theory of business ecosystem, Moore (1993) states co-evolution in his definition of the business ecosystem as "organizations and individuals... coevolve their capabilities and roles and tend to align themselves in the ecosystem ". Later on, value co-creation and co-evolution become one of the primary research focuses, e.g., (Peltoniemi et al. 2004; Tanev et al. 2010). However, the indicators and assessment of ecosystem conditions have not been addressed systematically as in the ecological ecosystem domain. In the ecological ecosystem field, assessment and indicators of ecosystem conditions (European Union 2013) (Maes et al. 2018) and ecosystem change (Elmqvist et al. 2003)

(c) The Author(s) 2022. Open Access This article is licensed under a Creative Commons Attribution 4.0 International License, which permits use, sharing, adaptation, distribution and reproduction in any medium or format, as long as you give appropriate credit to the original author(s) and the source, provide a link to the Creative Commons licence, and indicate if changes were made. The images or other third party material in this article are included in the article's Creative Commons licence, unless indicated otherwise in a credit line to the material. If material is not included in the article's Creative Commons licence and your intended use is not permitted by statutory regulation or exceeds the permitted use, you will need to obtain permission directly from the copyright holder. To view a copy of this licence, visit http:// creativecommons.org/licenses/by/4.0/. 
have been popularly discussed. Based on the experience from the ecological ecosystem domain, the indicators and assessment of business ecosystem conditions are essential for understanding current ecosystem conditions, future ecosystem trends, and differences across business ecosystems.

From the system engineering perspective, system dynamics are used to identify attractors and properties of a system (Bousquet and Le Page 2004), represent, explore and simulate the complex feedback and interactions among system elements (Elsawah et al. 2017). However, the evolution/co-evolution perspective is rarely discussed although there are discussions in, e.g., system thinking (Rubenstein-Montano et al. 2001), machine logic (Polic and Jezernik 2005), or risk management/ assessment (Sage and Rouse, 2014).

\section{CSTEP: five critical business ecosystems dimensions}

Therefore, to fill the gap, five critical business ecosystems dimensions called CSTEP are proposed for systematically understanding a targeted business ecosystem:

Climate, environment, and geographic situation.

Societal culture and demographic environment.

Technology (Infrastructure, technological skills, technology readiness).

Economy and finance.

Policies and regulation.

The CSTEP covers five influential dimensions that impact a specific business environment, and it is difficult to have universal definitions that apply to every business ecosystem. A general definition of CSTEP dimensions and sub-dimensions can be described as shown in Table 1. The explanation is based on the definitions from the Cambridge Dictionary and other authorities, such as NASA and United Nations.

Meanwhile, the five CSTEP dimensions can be divided into macro and micro levels based on the focuses (general or specific) of the business ecosystems. The main difference between these two is either from the ecosystem perspective or from the individual stakeholder perspective. For instance, for microgrid design, it is necessary to investigate the macro level of the C-dimension. Comparatively, for smart building development, the micro-level of the $\mathrm{C}$-dimension is more important. Table 2 summarizes the general matters for each CSTEP dimension at both macro and micro levels in the energy domain.

\section{The proposal of a novel CSTEP ecosystem analysis and evaluation method}

The CSTEP has been applied in energy ecosystems with various cases, e.g., microgrid design (Ma et al. 2018) and evaluation of dynamic distribution tariffs (Christensen et al. 2021). These applications show that the CSTEP can be used to analyze energy ecosystems, identify opportunities \& solutions and their impacts.

However, a methodology is needed to clearly introduce and elaborate the process to apply CSTEP for analyzing and evaluating business ecosystems. Based on previous studies, the methodology should cover three aims:

- Business opportunity identification. By investigating unmet needs and megatrends in a given business ecosystem, the future/ideal ecosystems can be portrayed, and the correlated business opportunities can be identified. 
Table 1 Definitions of CSTEP five dimensions

\begin{tabular}{|c|c|c|}
\hline Dimension & Sub-dimension & Explanation \\
\hline \multirow[t]{3}{*}{$\begin{array}{l}\text { Climate, environmental and geo- } \\
\text { graphic situation }\end{array}$} & Climate & $\begin{array}{l}\text { The general weather (including } \\
\text { seasons) conditions that are usually } \\
\text { found in a particular place }\end{array}$ \\
\hline & Environment & $\begin{array}{l}\text { The conditions that people live, work } \\
\text { or spend time in and the way that } \\
\text { they influence how they feel, behave } \\
\text { or work }\end{array}$ \\
\hline & Geographic situation & $\begin{array}{l}\text { The natural features of a place, such } \\
\text { as mountains and rivers }\end{array}$ \\
\hline \multirow[t]{2}{*}{$\begin{array}{l}\text { Societal culture, demographic } \\
\text { environment }\end{array}$} & Societal culture & $\begin{array}{l}\text { The way of life or work, especially } \\
\text { the general customs and beliefs, of a } \\
\text { society or an organization }\end{array}$ \\
\hline & Demographic environment & $\begin{array}{l}\text { The demography of an area is the } \\
\text { number and characteristics of the } \\
\text { people who live in an area, in relation } \\
\text { to their age, sex, if they are married } \\
\text { or not, etc }\end{array}$ \\
\hline \multirow[t]{4}{*}{ Technology readiness } & Infrastructure & $\begin{array}{l}\text { The basic systems and services, such } \\
\text { as transport and power supplies, } \\
\text { that a place uses in order to work } \\
\text { effectively }\end{array}$ \\
\hline & Technology development capacity & $\begin{array}{l}\text { The set of capacities to plan for } \\
\text { technology transfer and development } \\
\text { to achieve regional and national } \\
\text { goals (United Nations Department of } \\
\text { Economic and Social Affairs 2013) }\end{array}$ \\
\hline & Technology maturity & $\begin{array}{l}\text { Refer to the Technology Readiness } \\
\text { Levels (TRL) for assessing the maturity } \\
\text { level of a particular technology (NASA } \\
\text { 2021) }\end{array}$ \\
\hline & Technological skills & $\begin{array}{l}\text { The knowledge and expertise needed } \\
\text { to accomplish complex actions, tasks } \\
\text { and processes relating to computa- } \\
\text { tional and physical technology }\end{array}$ \\
\hline \multirow[t]{2}{*}{ Economy and finance } & Economy & $\begin{array}{l}\text { Economy related to market trade, } \\
\text { industry }\end{array}$ \\
\hline & Finance & $\begin{array}{l}\text { Cost of labour, material, maintenance, } \\
\text { and service Revenue from sales, } \\
\text { income, compensation, Return-on- } \\
\text { Investment }\end{array}$ \\
\hline \multirow[t]{2}{*}{ Policies and regulation } & Policy & $\begin{array}{l}\text { the activities of the government, } \\
\text { members of law-making organiza- } \\
\text { tions, or people who try to influence } \\
\text { the way a country is governed }\end{array}$ \\
\hline & Regulation & $\begin{array}{l}\text { An official rule or the act of control- } \\
\text { ling something }\end{array}$ \\
\hline
\end{tabular}

- Technology feasibility evaluation. With defined CSTEP multi-dimensional criteria, selected technologies are evaluated based on their impacts on the business ecosystem. Therefore, technologies that can benefit the business ecosystem and its stakeholders the most will be adopted. 
Table 2 Macro and micro levels of the five CSTEP dimensions

\begin{tabular}{|c|c|c|}
\hline Dimension & Macro-level & Micro-level \\
\hline $\begin{array}{l}\text { Climate, environmental and geo- } \\
\text { graphic situation }\end{array}$ & $\begin{array}{l}\text { Climate and geographic situation: } \\
\text { the general weather conditions and } \\
\text { the natural features of a place, e.g } \\
\text {-Nature resources (e.g., wind, solar, } \\
\text { natural gas) } \\
\text {-Natural disasters (e.g., earthquake, } \\
\text { tsunami) } \\
\text {-Climate zone }\end{array}$ & $\begin{array}{l}\text { Environment: the living, working or } \\
\text { production environment or condi- } \\
\text { tions e.g., } \\
\text { - Temperature } \\
\text { - Humidity } \\
\text { - Lighting } \\
\text { - } \mathrm{CO}_{2} \text { ' } \\
\text {-Noise, TVOC, PM2.5, etc } \\
\text {-Pollution }\end{array}$ \\
\hline $\begin{array}{l}\text { Societal culture, demographic } \\
\text { environment }\end{array}$ & $\begin{array}{l}\text { Demographic environment: the } \\
\text { demography of an area is the } \\
\text { number and characteristics of } \\
\text { the people who live in an area, in } \\
\text { relation to their age, sex, if they are } \\
\text { married or not, etc. E.g., } \\
\text {-Population } \\
\text { - Gender equality } \\
\text {-Public safety } \\
\text {-Societal stability } \\
\text { - Corruption } \\
\text {-Cultural dimension } \\
\text {-Social relations } \\
\text {-Education }\end{array}$ & $\begin{array}{l}\text { Societal culture: organizational/ } \\
\text { market/sectoral interests, concerns, } \\
\text { beliefs, e.g., } \\
\text {-Convenience } \\
\text {-Uncertain avoidance } \\
\text {-Cost-benefit acceptance } \\
\text {-Social/ environmental welfare, secu- } \\
\text { rity (e.g., environment concern) }\end{array}$ \\
\hline $\begin{array}{l}\text { Technology (Infrastructure, facili- } \\
\text { ties, technological skills, technology } \\
\text { readiness) }\end{array}$ & $\begin{array}{l}\text {-Infrastructure: the basic systems } \\
\text { and services, such as transport and } \\
\text { power supplies, that a place uses to } \\
\text { work effectively } \\
\text {-Technology development capacity: } \\
\text { The set of capacities to plan for } \\
\text { technology transfer and develop- } \\
\text { ment to achieve regional and } \\
\text { national goals (United Nations } \\
\text { Department of Economic and } \\
\text { Social Affairs 2013) }\end{array}$ & $\begin{array}{l}\text {-Technology Readiness Levels (TRL) } \\
\text { for assessing the maturity level of a } \\
\text { particular technology (NASA 2021) } \\
\text {-Technological skills: the knowledge } \\
\text { and expertise needed to accomplish } \\
\text { complex actions, tasks and processes } \\
\text { relating to computational and physi- } \\
\text { cal technology }\end{array}$ \\
\hline Ecconomy and finance & $\begin{array}{l}\text { Economy relates to market, trade, } \\
\text { industry, e.g } \\
\text {-Employment rate } \\
\text {-Living costs } \\
\text {-Investments } \\
\text { - Growth rate } \\
\text {-Financial stability } \\
\text {-Inflation rate }\end{array}$ & $\begin{array}{l}\text { Finance relates to cost and revenue: } \\
\text { - Cost, e.g., energy bill, labour, material } \\
\text { (e.g. resources, raw material), mainte- } \\
\text { nance (e.g., facilities), and service fees } \\
\text { - Revenue, e.g., sales, income, com- } \\
\text { pensation, Return-on-Investment }\end{array}$ \\
\hline Policies and regulation & $\begin{array}{l}\text { Policy: the activities of the govern- } \\
\text { ment, members of law-making } \\
\text { organizations, or people who try } \\
\text { to influence the way a country is } \\
\text { governed, e.g., } \\
\text {-Climate agenda/goals } \\
\text {-Political focus areas }\end{array}$ & $\begin{array}{l}\text { Regulation: an official rule or the act } \\
\text { of controlling something, e.g } \\
\text {-Laws } \\
\text {-Regulations } \\
\text { - Incentive/compensation scheme }\end{array}$ \\
\hline
\end{tabular}

- Technology transfer possibility investigation. With the identified commonality and variability of the chosen business ecosystems, the potentials of exporting the targeted technology from one ecosystem to another and the conditions can be identified. Furthermore, strategies for technology localization can be investigated and evaluated based on the result. 


\section{Future works}

As described above, each of the three aims has its focus. Therefore, three sub-methods should be developed correspondingly. Meanwhile, related activities and expected outcomes should be presented and explained with cases and examples of energy ecosystems. It can facilitate the understanding of the method and applications in the energy sector. Furthermore, the correlation with other parts in the business ecosystem modelling framework should be introduced and explained to provide coherence of the whole framework.

\section{Authors' contributions}

The author read and approved the final manuscript.

\section{Declarations}

Competing interests

The authors declare that they have no competing interests.

Published online: 28 February 2022

\section{References}

Aguilar FJ (1967) Scanning the business environment. Macmillan, London

Bousquet F, Le Page C (2004) Multi-agent simulations and ecosystem management: a review. Ecol Model 176(3):313-332. https://doi.org/10.1016/j.ecolmodel.2004.01.011

Brown A, Weiner E (1984) Supermanaging: how to harness change for personal and organizational success. McGraw-Hill, New York

Christensen K, Ma Z, Jørgensen BN (2021) Technical, economic, social and regulatory feasibility evaluation of dynamic distribution tariff designs. Energies 14(10):2860

Davenport TH, Prusak L (1997) Information ecology: mastering the information and knowledge environment. Oxford University Press Inc, Oxford

Elmqvist T, Folke C, Nyström M, Peterson G, Bengtsson J, Walker B, Norberg J (2003) Response diversity, ecosystem change, and resilience. Front Ecol Environ 1(9):488-494. https://doi.org/10.1890/1540-9295(2003)001 [0488:Rdecar] 2.0.Co; 2

Elsawah S, Pierce SA, Hamilton SH, van Delden H, Haase D, Elmahdi A, Jakeman AJ (2017) An overview of the system dynamics process for integrated modelling of socio-ecological systems: Lessons on good modelling practice from five case studies. Environ Model Softw 93:127-145. https://doi.org/10.1016/j.envsoft.2017.03.001

European Union. (2013). Mapping and Assessment of Ecosystems and their Services—an analytical framework for ecosystem assessments under Action 5 of the EU Biodiversity Strategy to 2020. http://ec.europa.eu/environment/ nature/knowledge/ecosystem_assessment/pdf/MAESWorkingPaper2013.pdf. Accessed 30 Jan 2022

Ma Z (2019) Business Ecosystem modeling - The Hybrid of System Modeling and Ecological Modeling: An application of the smart grid. Energy Informatics. https://doi.org/10.1186/s42162-019-0100-4

Ma Z, Christensen K, Jørgensen BN (2021) Business ecosystem architecture development: a case study of Electric Vehicle home charging. Energy Informatics 4(1):9. https://doi.org/10.1186/s42162-021-00142-y

Ma, Z., Billanes, J. D., \& Jørgensen, B. N. (2017, June 8-10, 2017). A Business Ecosystem Driven Market Analysis: The Bright Green Building Market Potential. Paper presented at the The 1st Annual International Conference of the IEEE Technology and Engineering Management Society, Santa Clara, California USA.

Ma, Z., Santos, A. Q., Gamborg, F., Nielsen, J. F., Johannesen, J. M., Jensen, M. D. H., Jørgensen, B. N. (2018, 22 - 25 May 2018). Solutions for Remote Island Microgrids: Discussion and analysis of Indonesia's remote island energy system. Paper presented at the The International Conference on Innovative Smart Grid Technologies (IEEE PES ISGT Asia 2018), Singapore.

Ma, Z., Broe, M., Fischer, A., Sørensen, T. B., Frederiksen, M. V., \& Jøergensen, B. N. (2019, 12-15 June 2019). Ecosystem Thinking: Creating Microgrid Solutions for Reliable Power Supply in India's Power System. Paper presented at the 2019 1st Global Power, Energy and Communication Conference (GPECOM).

Maes, J., Teller, A., Erhard, M., Grizzetti, B., Barredo, J., Paracchini, M., Werner, B. (2018). Mapping and Assessment of Ecosystems and their Services- An analytical framework for mapping and assessment of ecosystem condition in EU. Luxembourg. http://ec.europa.eu/environment/nature/knowledge/ecosystem_assessment/pdf/5th\%20MAES\% 20report.pdf. Accessed 30 Jan 2022

Moore JF (1993) The death of competition: leadership and strategy in the age of business ecosystems. Harper Paperbacks, New York

NASA. (2021). Technology Readiness Level. https://www.nasa.gov/directorates/heo/scan/engineering/technology/techn ology_readiness_level. Accessed 30 Jan 2022 
Peltoniemi, M., \& Vuori, E. (2004). Business ecosystem as the new approach to complex adaptive business environments. Paper presented at the FeBR 2004: Frontiers of e-business research 2004, Tampere, Finland.

Polic A, Jezernik K (2005) Closed-loop matrix based model of discrete event systems for machine logic control design. IEEE Trans Industr Inf 1(1):39-46. https://doi.org/10.1109/TII.2005.844424

Rubenstein-Montano B, Liebowitz J, Buchwalter J, McCaw D, Newman B, Rebeck K (2001) A systems thinking framework for knowledge management. Decis Support Syst 31(1):5-16. https://doi.org/10.1016/S0167-9236(00)00116-0

Sage AP, Rouse WB (2014) Handbook of systems engineering and management. Wiley, Hoboken

Tanev, S., Thomsen, M. S., \& Ma, Z. (2010). Value co-creation: from an emerging paradigm to the next practices of innovation. Paper presented at the The 3rd ISPIM Innovation Symposium, Quebec, Canada.

United Nations Department of Economic and Social Affairs. (2013). Technology Readiness. https://sustainabledevelopme nt.un.org/content/documents/1953UNDP.pdf.Accessed 30 Jan 2022

\section{Publisher's Note}

Springer Nature remains neutral with regard to jurisdictional claims in published maps and institutional affiliations.

\section{Submit your manuscript to a SpringerOpen ${ }^{\circ}$} journal and benefit from:

- Convenient online submission

- Rigorous peer review

- Open access: articles freely available online

- High visibility within the field

- Retaining the copyright to your article

Submit your next manuscript at $\boldsymbol{\nabla}$ springeropen.com 